\title{
The Rhodiascit system-individual response to reinfusion possibly related to angiotensin sensitivity. Preliminary results
}

\author{
L. VAN WAES \\ M.D.
}

\author{
M. SCHURGERS \\ M.D.
}

\author{
L. Demeulenaere \\ M.D. \\ Department of Medicine, St Andriesziekenhuis B-8880 Tielt, Belgium
}

\begin{abstract}
Summary
Results are reported of the effect of ascites reinfusion with concentration in seventeen patients. Complications were few and best results were obtained when the patient was also given frusemide during the reinfusion. The diuretic response to the reinfusion appeared to be determined by the pre-existing sensitivity of the circulation to intravenously administered angiotensin.
\end{abstract}

\section{Introduction}

The effectiveness of reinfusion of concentrated ascitic fluid (Rhodiascit system) in treatment of 'refractory ascites' is well established (Lévy et al., 1971). Besides this absolute indication its usefulness has been stressed in situations that require quick drying up of the ascites (Van Waes, van Quickenborne and Demeulenaere, 1973). Our experience with this technique has been previously reported (Van Waes and Demeulenaere, 1973; Van Waes et al., 1973). Attention has been drawn to the strikingly different individual response after this treatment. Purely symptomatic in some, reinfusion seems to induce more lasting effects in others, e.g. by restoring the lost equilibrium in acute decompensation upon a well defined and controllable cause; by reset of the sensitivity to diuretic treatment in patients who became refractory to it; perhaps by the possibility to increase the interval between subsequent reinfusions in absence of a significant variation in liver function.

In this paper we shall only emphasize the immediate effects of reinfusion on diuresis and sodium excretion, and longterm behaviour of the patients after reinfusion.

\section{Material and methods (Table 1)}

Forty reinfusions of concentrated ascitic fluid

Reprint requests to: Dr L. Van Waes, St Andriesklinick, B-8880 Tielt, Belgium.
(Rhodiascit system) were performed on seventeen patients aged from 34-72 years (average 58). Basic pathology consisted of cirrhosis in fifteen (postnecrotic eight; alcoholic six ; cryptogenic one); metastatic infiltration of the liver in one; segmental portal hypertension without cirrhosis in one. In all patients, ascites was the most prominent feature on presentation and had lasted for several months, except in four who presented with an acute decompensation of the disease.

Indications for performing Rhodiascit are sum marized in Table 2 . In most patients, ascites had? become refractory to previous treatment with diuretics and salt restrictve diet. Obviously this refractoriness was elicited by 'overtreatment' in most instances. Conventional therapy with diuretics was not recommended in one patient (case 3 ) with restricted blood volume of 4 litres before treatment and in another with functional renal failure (case 10). In a psychiatric patient, it was discarded because of unreliability of the patient (case 7). On fourteen occasions, Rhodiascit was selectively performed aiming at a quick drying up of the ascites as was required in preparation for laparoscopy or shunt intervention and for symptomatic relief in a case with tense ascites. In three cases with acute decompensation, prompt re-establishment of the lost equilibrium was thought advantageous once the eliciting factor (bleeding two, severe diarrhoea one) was under control.

Eight patients were repeatedly treated, sometimes for different indications.

In twelve patients angiotensin sensitivity was assessed according to Kaplan and Silah (see Bourel et al., 1968) both before and after reinfusion. For this purpose, pressor response to a trigger dose of $7.5 \mathrm{ng} / \mathrm{kg}$ body weight was studied.

After reinfusion, patients were all kept on a salt restrictive diet containing $14 \mathrm{mEq}$ of sodium and spironolactone $100 \mathrm{mg}$ daily. 
TABLE 1. Rhodiascit. Duration of ascites, previous treatment and follow-up after reinfusion in seventeen patients

\begin{tabular}{|c|c|c|c|c|c|}
\hline $\begin{array}{c}\text { Case } \\
\text { no. }\end{array}$ & $\begin{array}{c}\text { Duration of } \\
\text { ascites } \\
\text { (in months) }\end{array}$ & Previous treatment & $\begin{array}{l}\text { No. of } \\
\text { reinfusions }\end{array}$ & $\begin{array}{l}\text { Evolution } \\
\text { ascites }\end{array}$ & Follow-up \\
\hline 1 & 6 & Diet-diuretics-paracentesis & 3 & Absent & 30 months \\
\hline 2 & 5 & Diet-diuretics & 1 & Reaccumulated & Died (haemorrhage) \\
\hline 3 & Acute & 一 & 1 & Absent & 24 months \\
\hline 4 & 2 & - & 5 & Interval $\uparrow$ & Died (hep. coma) \\
\hline 5 & 6 & Diet-diuretics-paracentesis & 1 & Reaccumulated & Died (haemorrhage) \\
\hline 6 & 12 & Diet-diuretics & 1 & Absent & 30 months \\
\hline 7 & Unknown & - & 6 & Reaccumulated & Died (haemorrhage) \\
\hline 8 & 4 & Diet-diuretics & 1 & Stabilized & 7 months \\
\hline 9 & Acute & Diet-diuretics-portacaval shunt & 3 & Reaccumulated & Died (haemorrhage) \\
\hline 10 & Acute & Diet-diuretics & 6 & Reaccumulated & Died (hep. coma) \\
\hline 11 & 7 & Diet-diuretics & 1 & Stabilized & 6 months \\
\hline 12 & 2 & Diet-diuretics & 1 & Unknown & \\
\hline 13 & 1 & Diet-diuretics & 3 & Reaccumulated & \\
\hline 14 & 1 & Diet-diuretics & 1 & Stabilized & 7 months \\
\hline 15 & 1 & Diuretics & 2 & Reaccumulated & Died (hep. coma) \\
\hline 16 & 4 & Diet-diuretics & 3 & Reaccumulated & Died (haemorrhage) \\
\hline 17 & Acute & - & 1 & Absent & 4 months \\
\hline
\end{tabular}

TABLE 2. Indications for Rhodiascit in forty reinfusions on seventeen patients. Several patients were repeatedly treated for a different indication

Imperative: 'intractable ascites'

Ascites refractory to diuretics and salt restriction

Conventional therapy contraindicated or impractical

$\begin{array}{ll}\text { Unreliability of patient } & 4 \\ \text { Hypovolaemia } & 3 \\ \text { Renal failure } & 1\end{array}$

4
3

Selective: aiming for a quick drying up

In preparation for laparoscopy/surgery 9

$\begin{array}{ll}\text { Symptomatic relief (tense ascites) } & 2 \\ \text { Acute decompensation } & 3\end{array}$

Total

Interval in days
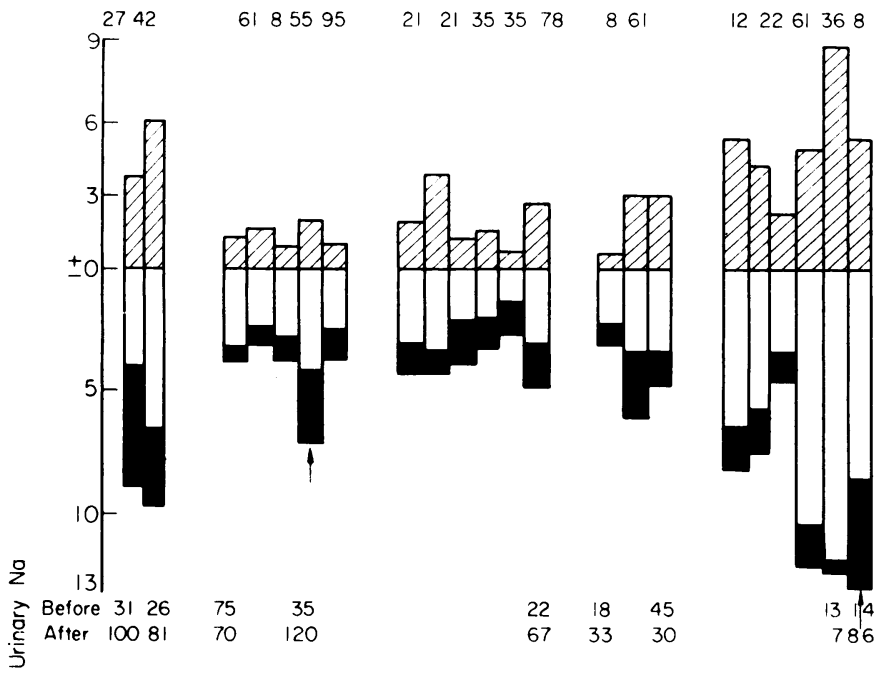

$21251 \quad 11 \quad 6441$

FIG. 1. Rhodiascit. Relative amount of concentrate, ultrafiltrate and urinary output. Each complex of columns represents data on subsequent reinfusions in the same patient. Interval in days between subsequent reinfusions; urinary sodium excretion in $\mathrm{mEq} / \mathrm{l}$ before and after reinfusion. $\mathbb{Z}$, Concentrate; $\square$, ultra filtrate; $\square$, urinary output $24 \mathrm{hr}$ after reinfusion; $\uparrow$, frusemide. 


\section{Results}

Immediate effect on sodium excretion and diuresis (Fig. 1)

Only patients who underwent multiple reinfusions are considered. Data concerning reinfusions on the same patient are grouped, each patient thus serving as his own control. Increased sodium excretion and diuresis after Rhodiascit was rarely observed and was unrelated to the amount that was reinjected. Addition of $40 \mathrm{mg}$ of frusemide to the reinfusate invariably resulted in an increased diuresis and sodium excretion as compared to previous treatments. This effect lasted usually for $2-3$ weeks after reinfusion. No adverse effects on renal function were observed afterwards, and serum potassium concentration always remained in the pre-treatment range. One patient (case 10) developed severe hyponatraemia of $115 \mathrm{mEq} / \mathrm{l}$ in the weeks following massive reinfusion.

\section{Long-term follow-up after reinfusion (Table 1)}

Eight patients died, five following variceal bleeding independent of reinfusion, and three in hepatic coma. In each of these reaccumulation of ascites occurred after the reinfusion, necessitating a repeat reinfusion in six.

Four patients, cases 1, 3, 6 and 17, have remained free of ascites for periods of $30,24,30$, and 4 months respectively. Case 1 underwent a shunt operation following reinfusion. Cases 3 and 17 were each first seen during acute hepatic decompensation and after correcting the precipitating factors equilibrium was restored after one reinfusion. Case 6 was resistant to diuretics before reinfusion but responded well afterwards.

Patients 8,11 and 14 were resistant to diuretics but became sensitive after one reinfusion. However, a small amount of fluid remains in each of these patients at 7,6 and 7 months of follow-up respectively.

Case 13 requires repeated reinfusions and case 12 has been lost to follow-up.

The patients could be divided into three groups on the basis of their response to angiotensin. The first group (cases 3,6 and 17) were sensitive both before and after reinfusion. The second group (cases 7, 9, 10 and 13) were refractory to angiotensin both before and after reinfusion. The third group (cases 1, 2, 4, 8 and 14) were refractory before but regained sensitivity after reinfusion. This correlates with the clinical behaviour results from Table 1 . In the first group, ascites is absent in all three patients; in the second group, a relapse into ascites formation was constantly observed; in the third group ascites is absent in one patient; stabilization occurred in two; whereas in the remaining two a relapse into ascites formation was seen. However, in the one who was repeatedly treated, increase of the interval between subsequent reinfusions was observed.

\section{Comments}

Complementary effects of diuretics and ascites reinfusion on diuresis and sodium excretion in cirrhosis has previously been reported (Eknoyan et al., 1970). Whereas ascitic fluid-infusion alone increased renal perfusion, GFR and potassium excretion, it did not affect urine volume nor sodium excretion. On the other hand frusemide alone resulted in an increased urinary output, sodium and potassium excretion without effect on GFR or renal plasma flow. Furthermore, by adding the frusemide to the reinfusate, the inherent hazard of further impairment of the general circulation is cancelled. In our patients a small dose of frusemide during reinfusion invariably resulted in a marked diuresis and sodium excretion. Hypokalaemia was not observed in our patients afterwards, although this complication must be kept in mind especially when larger doses of the diuretic are used. Diuretics during reinfusion are mainly indicated to prevent hyperhydration (Cressy et al., 1972) in those patients without increased urinary output during reinfusion. However, in those cases an immediate and voluminous rediffusion into the abdominal cavity obviously must have a protective role. This was illustrated by one of our patients who had no clinical evidence of overfilling although the reinjected volume exceeded the urinary output by about 91 .

Preliminary results suggest a correlation between the state of angiotensin sensitivity (assessed by the test of Kaplan and Silah) and clinical behaviour of the patient after Rhodiascit. Indeed, best results were obtained on patients who were sensitive to the pressor dose reflecting their capacity of physiological regulation of water and electrolyte metabolism. Perhaps the 'reset' of angiotensin sensitivity after reinfusion could partially explain the more durable effect observed on some patients.

\section{References}

Bourel, M., Pirot, D., Lenotr, P., Chauvel, A., PawlotSKY, Y. \& Simon, M. (1968) Contribution à l'étude de l'intervention du système rénine-angiotensine-aldostérone au cours de l'évolution des hépatopathies alcooliques chroniques. Revue internationale d'Hépatologie, 18, 871.

Cressy, G., Jehan, P., Brissot, P., Simon, M., Gastard, J. \& Bourel, M. (1972) Utilisation thérapeutique du liquide d'ascite au cours de la cirrhose du foie. II. La méthode de réinjection continue. Archives médicales de l'Ouest, 4, 829.

Eknoyan, G., Martinez-Maldonado, M., Yium, J.J. \& Suk I, W.N. (1970) Combined ascitic-fluid and furosemide infusion in the management of ascites. New England Journal of Medicine, 282, 713.

Lévy, V.G., Hecht, Y., Georgacopoulos, H., Hadchouel, P., Touboul, J.P., Sausse, A., Granger, A., Stern, A. \& 
Caroli, J. (1971) Assèchement des ascites cirrhotiques par réinjection veineuse continue du liquide d'ascite concentré. Annales de médecine interne, 122, 1075.

Van Waes, L. \& Demeulenaere, L. (1973) Behandeling van "onbehandelbare ascites" door continue punctiereinfusie. Het Rhodiascitsysteem. Tijdschrift voor Gastroenterologie, 16, 396.
Van Waes, L., Van Quickenborne, G. \& Demeulenaere, L. (1973) Traitement de l'ascite cirrhotique par réinfusion veineuse mécanique (système Rhodiascit). Acta gastroenterologica belgica, 36, 200. 